\title{
What should organic farmers grow: heritage or modern spring wheat cultivars?
}

\author{
Anne-Kristin Løes $(\mathbb{D}) \cdot$ Randi B. Frøseth • Jon Arne Dieseth • Josefine Skaret • Caroline Lindö
}

Received: 8 April 2020 / Accepted: 23 April 2020 /Published online: 29May 2020

(C) The Author(s) 2020

\begin{abstract}
To achieve a complete organic value chain, we need organic seed from cultivars adapted to organic growing. A separate breeding for organic growing is difficult to achieve in small markets. Many breeding goals are equal for organic and conventional cereals, and cultivars failing to qualify as a commercial variety for conventional growing may possibly perform well in organic growing, with different regimes of fertilisation and plant protection. A field trial was conducted over 2 years to compare 25 cultivars of spring wheat, ranging from one land race and some old varieties released between 1940 and 1967, to modern market varieties and breeding lines. Grain yield, agronomic characteristics and grain and flour quality, including mineral content, were recorded. The performance of the 20 most interesting cultivars in artisan bread baking was measured, as were sensory attributes in sourdough
\end{abstract}

\author{
A.-K. Løes \\ Norwegian Centre for Organic Agriculture (NORSØK), Tingvoll, \\ Norway \\ e-mail: anne-kristin.loes@norsok.no \\ R. B. Frøseth $(\bowtie)$ \\ Norwegian Institute of Bioeconomy Research (NIBIO), Tingvoll, \\ Norway \\ e-mail: Randi.Froseth@nibio.no \\ J. A. Dieseth \\ Graminor AS, Hamar, Norway \\ J. Skaret \\ Nofima AS, Ås, Norway \\ C. Lindö \\ Stockholm, Sweden
}

bread from six cultivars. Modern varieties and breeding lines gave higher yields and had larger kernels, better grain filling, higher falling numbers and higher SDSsedimentation volumes compared with old cultivars. The old cultivars, on average, had higher concentrations of minerals, although the growing site had a strong effect on mineral concentrations. Bread from modern cultivars performed best in a baking test. Several sensory attributes such as juiciness, chew resistance, firmness, acid taste and vinegar odour varied significantly between the six tested cultivars. Land races and old varieties have an important cultural value, and many consumers are willing to pay a premium price for such products. This will be required since yield levels are often considerably lower, especially with humid weather conditions at harvest.

Keywords Cereal breeding; grain quality · Baking test . Sensory analysis

\section{Introduction}

Wheat (Triticum aestivum var. aestivum) is an important food crop, and the main ingredient in Norwegian bread. About 320,000 tons of wheat are milled to flour for human consumption annually in Norway, comprising about $80 \%$ of the total milled volume (Norwegian Agriculture Agency 2019). Within the organic sector, there is a high interest for heritage varieties of cereals, including spelt (Triticum aestivum var. spelta), emmer (Triticum turgidum var. dicoccum) and einkorn (Triticum monococcum var. monococcum). However, 
these varieties were traditionally not grown in Norway and are not included in the Norwegian plant heritage. Along with land races and old cultivars, such wheat varieties are claimed to possess better characteristics than modern cultivars in several respects (e.g. Martineau 2016). People experiencing digestive problems when eating bread made by industry baking with flour from modern cultivars may experience no digestive problems when eating bread made from heritage varieties, land races or old cultivars. It is also often claimed that heritage varieties and old wheat cultivars are more nutritious due to higher concentrations of minerals in the grains, since breeding for higher yields have caused a "dilution effect" where more grains contain relatively more starch and less minerals per kilogram. This argument is supported by scientific studies (e.g. Fan et al. 2008; Zhao et al. 2009). Zhao et al. (2009) found a generally negative relationship between grain yield and concentration of proteins, zinc ( $\mathrm{Zn}$ ) and sulphur (S) in 175 lines of wheat grown in a field experiment in Hungary in 2004-2005. The study comprised 150 lines of bread wheat (130 of winter wheat, 20 of spring wheat), out of which 59 were characterised as land races, old varieties or transitional varieties, with long straw. Furthermore, the trial comprised 15 heritage varieties (spelt, emmer, einkorn) and 10 durum wheat (Triticum turgidum var. durum). The time span of the year which bread wheat varieties in the data set was released, ranging from 1948 to 2003. Durum wheat was comparable to the bread wheat with respect to grain concentrations of $\mathrm{Zn}$, iron (Fe) and selenium (Se), with a mean value for these groups of $21 \mathrm{mg} \mathrm{Zn,} 36 \mathrm{mg} \mathrm{Fe}$ and $90 \mu \mathrm{g}$ Se per $\mathrm{kg}$. On average for the 15 heritage varieties, these concentrations were 23, 41 and 239. For the whole data set, Zhao et al. (2009) also found a significant and negative relationship between grain yield and bran yield, and positive relationships between grain yield and thousand kernel weight and kernel diameter. A subset of 26 bread wheat varieties, released between 1948 and 2003, showed a significantly decreasing trend for grain $\mathrm{Zn}$ concentration over time, whereas for Fe the trend was less apparent (Zhao et al. 2009).

Fan et al. (2008) analysed concentrations of Fe, Zn, copper $(\mathrm{Cu})$, manganese $(\mathrm{Mn})$, phosphorus $(\mathrm{P}), \mathrm{S}$ and calcium $(\mathrm{Ca})$ in totally 362 wheat grain samples stored in the archive of the Rothamsted Broadbalk Experiment close to London, UK. The period of study was from 1845-2005, and comprised 16 varieties of winter wheat, which were in each year one of the most commonly grown varieties at that time. The authors draw a line of distinction in 1967; since before this year, varieties had long straw whereas after 1967 breeding for higher harvest index and short straw changed the morphology of wheat varieties significantly. For most minerals, the average concentration in winter wheat samples taken between 1968 and 2005 were significantly lower than for samples taken before 1968, and most micronutrients showed a significant decreasing concentration over time in the most recent period. There was a negative relationship between mineral content and grain yield. Overall, mineral concentrations decreased by $20-30 \%$, and the authors explain this as a dilution effect due to the breeding aim of harvesting more grains and less straw (increased harvest index).

As also mentioned by Zhao et al. (2009) land races and old varieties commonly have longer straw, and it is a tempting idea that this may be related to an ability of the root system to better cope with restricted growing conditions such as drought or lack of mineral nutrients. However, as discussed by Rich and Watt (2013), studies of cereal root architecture in field are very time-consuming, and interactions between soil conditions and genotype cannot be excluded, hence making this a very challenging topic to confirm scientifically. What remains a fact is that farmers have always tried to increase their grain yields. So, when cereal breeding turned into a highly advanced field of research about 1900 to serve a more intensive agriculture, there were some good reasons to aim for characteristics where land races often performed poorly, such as resistance to fungal diseases, better resistance to lodging and resistance to pre-harvest sprouting. Such breeding goals, and since about 1970 also strong gluten quality as requested by the Norwegian bakeries, have guided the breeding of cereal cultivars in Norway (Graminor 2020). As a result, modern cultivars tend to give significantly higher yields, often with a better quality than old varieties and land races (Zhao et al. 2009). For every breeding line that qualifies as a commercial new cereal cultivar, there are many lines which do not pass the qualification. This may be due to reasons which are of less importance in organic growing (Table 1). For instance, it may be that a line with excellent agronomic characteristics has too "soft" gluten to perform well in industrial baking. Such discarded lines represent valuable genetic resources, which possibly may be valuable in organic growing, where a larger proportion of the produced wheat may be used for home baking or artisan baking where a "strong" gluten is less important. 
In Norway, the growing of spring wheat for bread making is challenging due to a short, cold and often wet growing season, and conditions get more challenging towards the North. Under such conditions, around the city of Steinkjer, $400 \mathrm{~km}$ south of the polar circle, a successful small company, Gullimunn AS (https://gullimunn.no/) which grows mills and distributes flour for artisan baking from locally grown cereals of old cultivars, heritage varieties and land races has been established. On this background, at this location, we studied a collection comprised of land races, old cultivars (approved 1940-1967), modern cultivars (approved 1970-2014) and breeding lines still under assessment for qualification as commercial cultivars for their performance under organic growing conditions and artisan baking. The aim of this study was to increase the diversity of cultivars used for growing of organic cereals, by searching for modern cultivars possibly performing well under organic growing conditions and with artisan baking in Mid-Norway. In the present paper, we present the achieved results and output of this study and discuss benefits and drawbacks of growing old or modern cultivars in organic farming. A comprehensive report, referring more detailed results of some characteristics, is available in Norwegian (Løes et al. 2019).

\section{Material and methods}

The study consisted of a field trial in 2 years, with subsequent grain quality analyses, including minerals, a baking test and sensory analyses.

\section{Field trial}

The field trial was conducted at two locations close to Steinkjer, Norway, during 2017 and 2018. At both experimental sites, we compared 25 lines of spring wheat, ranging from a Swedish land race to breeding lines still under testing. The experimental setup has a lattice design, with two replicates and plots sized $1.5 \mathrm{~m} \times 8 \mathrm{~m}$. In a lattice design, the replicates are grouped in subblocks according to a defined system, allowing for statistical corrections caused by variation in soil and other experimental conditions related to blocks. This arrangement reduced the experimental coefficient of variation $(\mathrm{CV})$ in both years.

The selection of varieties (Table 5) comprised old varieties grown and marketed by Gullimunn AS for artisan baking (Dala landhvete, Fram II), two other old Norwegian cultivars (Norrøna, Møystad), one cultivar representing the success story of early Norwegian wheat breeding (Runar), two Swedish cultivars (Polkka, with a "softer" gluten quality than most modern Norwegian varieties, and Sport with a very high protein concentration) and two common market cultivars in Norway during 2017-2018 (Mirakel, Seniorita). The variety Mirakel, which is quite tall, was originally bred for organic farming, but because of high yields, good disease resistance and exceptionally good baking quality, it has gained popularity among conventional farmers and is now the most grown wheat variety in Norway. The selection further comprised 16 breeding lines (from 2003 to 2017) from the Norwegian breeding company Graminor, where three had yielded well in former testing with organic growing conditions (GN12634, GN15621, GN16503), four had "soft" gluten (GN17632, 17633, 17634 and 176353) and nine were selected for vigorous early growth (remaining lines in Table 3). Seniorita also scored high on this characteristic, which was assessed in a separate study of about 200 spring wheat lines grown at Ås, Norway, in 2016 in the project "Expanding the technology base for Norwegian wheat breeding: genomic tools for breeding of highquality bread wheat" (Research Council of Norway (RCN) 2020).

The experimental sites were fertilised according to the farmer's practice (Table 2). Topsoil analysis ( 0 $20 \mathrm{~cm}$ ) from samples taken after harvest (Table 2) revealed that the soil's nutrient status was medium (P-AL between 5 and 7, K-AL between 7 and $15 \mathrm{mg} 100 \mathrm{~g}^{-1}$ air-dried soil) or high (P-AL between 8 and 14, K-AL

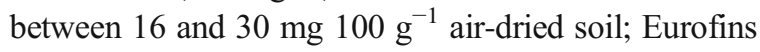
2020). Extractable nutrients in agricultural soil in Norway are assessed by extraction with $0.1 \mathrm{M}$ ammonium lactate and $0.4 \mathrm{M}$ acetic acid at pH 3.75 (AL-method; Egnèr et al. 1960). Seed planting occurred with an experimental seed planting machine, seeding rate $24 \mathrm{~g}$ seed $\mathrm{m}^{-2}$. For the 2017 trials, the seed was delivered from Gullimunn AS and Graminor AS. For the 2018 season, seed from the 2017 experiment yield was used. Weed harrowing was performed once before the wheat germinated, using the farmer's equipment. Harvesting occurred with an experimental combiner, where only grain yields were recorded.

In 2017, the growing season was initiated by a cold and dry spring, and a wet and cool and early summer 
Table 1 Differences in breeding aims for spring wheat aimed at being grown in conventional or organic farming

\begin{tabular}{lll}
\hline Trait & Importance in conventional growing & Importance in organic growing \\
\hline Early ground cover & + & ++ \\
Straw strength & +++ & + \\
Mildew resistance & ++ & + \\
Leaf spot disease resistance & ++ & +++ \\
Efficient N uptake & + & +++ \\
Requested plant morphology & Short straw, erect & Longer straw, broad leaves \\
Gluten adapted to industry baking & +++ & + \\
\hline
\end{tabular}

(Fig. 1). The amount of rain in June was high as compared with normal values in this area (Table 3). In late July, the weather changed, and harvest conditions were favourable with a warm and dry September. Despite a late start, the growing conditions were generally favourable for cereals in 2017 and yields were satisfactory. In 2018, the conditions were almost opposite. May was warm and dry, and the summer proceeded with very little precipitation. This affected negatively on cereal yields, with short straw and small grains. A very wet harvest with poor harvesting conditions further contributed to very low yield levels in that season.

Experimental plots were regularly observed, and characteristics such as days to maturity, length of straw and lodging were registered. The developmental stage was recorded by yellow ripening, using the $\mathrm{BBCH}$ scale (Lancashire et al. 1991). By this observation, plots with the cultivar Mirakel were used as a standard, and other plots assessed relative to these plots by giving a value of minus 1-8 days for earlier cultivars, 0 for similar cultivars and plus 1-4 days for later maturing cultivars (Table 4). By yellow ripening, the grain water content is $38 \%$. At this stage, the whole aboveground plant is yellow, except for some green colouring of the nodes. Straw length was recorded on the same date, by choosing one row of plants per plot and measuring the lengths of 10 typical straws. Lodging was recorded before harvest, as percentage of the plot with flat lying plants. For example, if the straw inclined $45 \%$ on $50 \%$ of the plot, a value of $25 \%$ lodging was recorded. At harvest, the fresh weight of grains was recorded, and a representative sample of about $1 \mathrm{~kg}$ used for determination of dry weight (DW). Grain yields are presented with a standard water content of $15 \%$. The samples used for DW

Table 2 Soil characteristics, pre-crops, fertilisation, soil tillage operations and dates for seed planting and harvest at the four experimental sites

\begin{tabular}{|c|c|c|c|c|}
\hline & \multicolumn{2}{|l|}{2017} & \multicolumn{2}{|l|}{2018} \\
\hline & Site 1 & Site 2 & Site 1 & Site 2 \\
\hline Soil type & Sandy silt & Clay loam & Clay loam & Silty sand \\
\hline Soil pH $\left(\mathrm{H}_{2} \mathrm{O}\right)$ & 6.1 & 6.4 & 5.8 & 6.3 \\
\hline Soil extractable $\mathrm{P}^{\mathrm{a}}$ & 6.0 & 6.4 & 9.5 & 12.0 \\
\hline Soil extractable $\mathrm{K}^{\mathrm{a}}$ & 17.0 & 7.0 & 15.0 & 7.0 \\
\hline Loss on ignition ${ }^{\mathrm{b}}$ & 6.9 & 3.0 & 4.1 & 2.8 \\
\hline Pre-crop & Spring wheat & 2nd year ley & Meadow & Barley \\
\hline Soil tillage in spring & Ploughing & Ploughing & Ploughing & Disc harrowing \\
\hline Type of fertiliser & Cattle slurry & Poultry manure & None & Chicken manure \\
\hline Date of seed planting & May 8 & May 11 & May 25 & May 21 \\
\hline Date of harvesting & Sept 27 & Sept 28 & Oct 2 & Sept 20 \\
\hline
\end{tabular}

${ }^{\mathrm{a}} \mathrm{mg}$ per $100 \mathrm{~g}$ air-dried soil

$\mathrm{b} \%$ weight of dry soil 


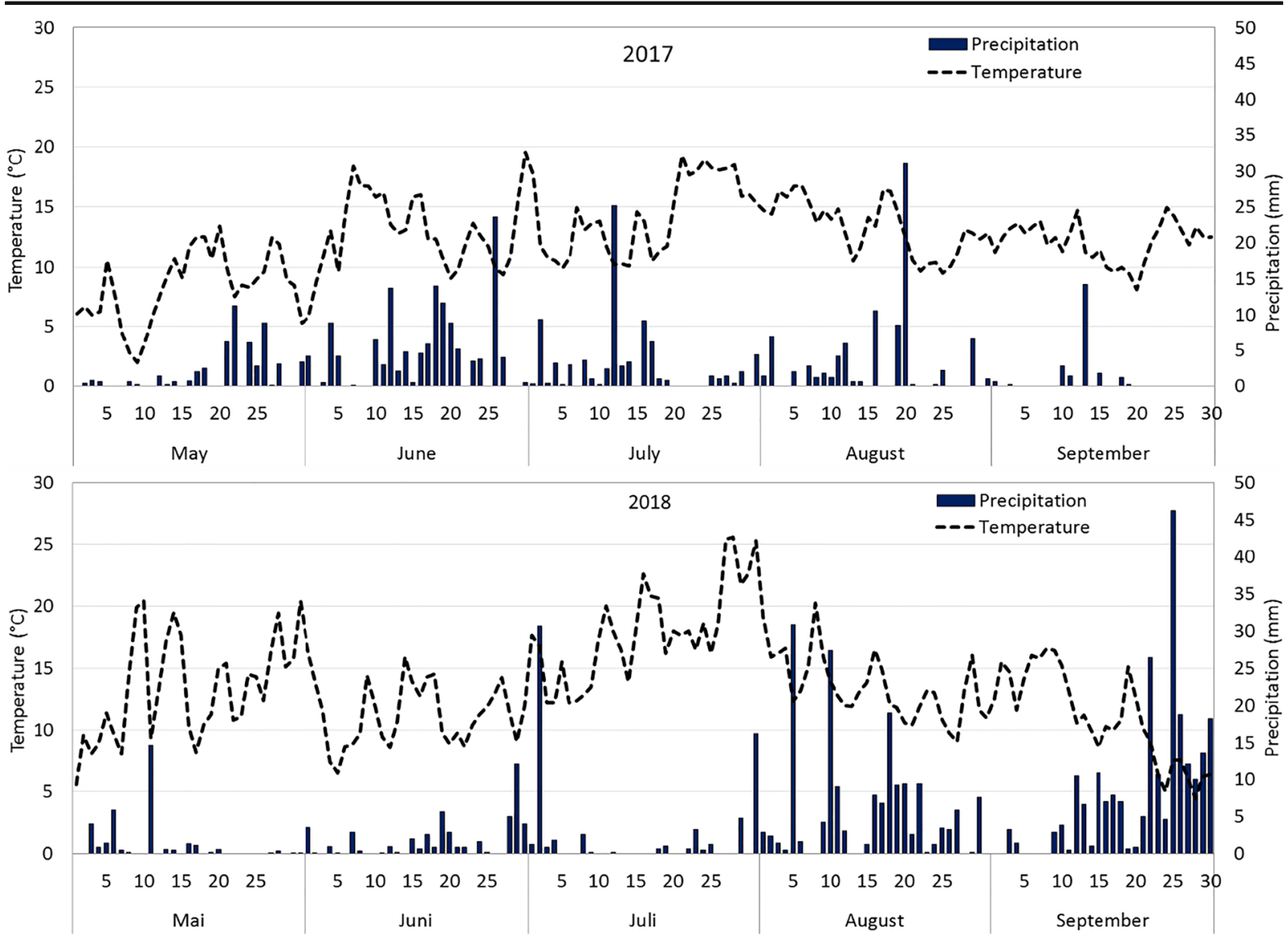

Fig. 1 Daily air temperature $2 \mathrm{~m}$ above ground level and precipitation during the growing seasons of 2017 and 2018 , recorded at Mære weather station https://lmt.nibio.no/historikk/34/)

determination were later used for grain quality measurements, conducted by Graminor.

Grain from 20 cultivars were selected by leaving out the five least promising breeding lines (GN) and used for analysis of minerals and test baking. The

Table 3 Mean values during 1991-2016, compared with values from 2017 and 2018, of monthly precipitation (mm) and air temperature $2 \mathrm{~m}$ above ground level $\left({ }^{\circ} \mathrm{C}\right)$ at Mære weather station near Steinkjer, Norway

\begin{tabular}{|c|c|c|c|c|c|c|}
\hline \multirow[b]{2}{*}{ Month } & \multicolumn{2}{|c|}{ 1991-2016 } & \multicolumn{2}{|l|}{2017} & \multicolumn{2}{|l|}{2018} \\
\hline & $\begin{array}{l}\text { Rain, } \\
\mathrm{mm}\end{array}$ & $\begin{array}{l}\text { Temp, } \\
{ }^{\circ} \mathrm{C}\end{array}$ & $\begin{array}{l}\text { Rain, } \\
\mathrm{mm}\end{array}$ & $\begin{array}{l}\text { Temp, } \\
{ }^{\circ} \mathrm{C}\end{array}$ & $\begin{array}{l}\text { Rain, } \\
\mathrm{mm}\end{array}$ & Temp,${ }^{\circ} \mathrm{C}$ \\
\hline May & 53 & 8.9 & 52 & 8.4 & 32 & 13.3 \\
\hline June & 65 & 11.9 & 134 & 12.9 & 42 & 11.3 \\
\hline July & 79 & 15.1 & 83 & 14.2 & 65 & 17.8 \\
\hline August & 85 & 14.0 & 89 & 13.7 & 170 & 13.5 \\
\hline September & 84 & 10.2 & 22 & 12.1 & 229 & 10.6 \\
\hline
\end{tabular}

lines not included here were GN12634, GN12741, GN14529 and GN17633, being very late in maturation and/or low in yield, and GN17634 being the only modern cultivar with a low falling number value in 2017.

Grain quality was described by water content at harvest, test weight, thousand grain weight, starch quality (falling number), protein content and technological protein quality measured as SDS-sedimentation volume (see below). Grain water content at harvest provides useful information about the earliness and ripeness status by harvest, provided that the harvested lines were not dead ripe (completely dead) because then the water content will be a function of precipitation or dew, not maturity. In our case, results of grain water content from 2017 are useful to evaluate earliness, whereas results from 2018 are less reliable due to very wet harvest conditions (Fig. 2). Dead ripeness occurs 7-10 days after yellow ripeness. 
Table 4 Sensory attributes in sourdough bread, produced in a sensory panel of 10 trained panellists

\begin{tabular}{|c|c|}
\hline Attribute & Description \\
\hline \multicolumn{2}{|l|}{ Odour } \\
\hline Total intensity-O & The strength of all odours in the product \\
\hline Sour-O & Related to a fresh, balanced odour, which is due to organic acids \\
\hline Vinegar-O & Related to an odour from vinegar (regular, apple cider, white wine) \\
\hline \multicolumn{2}{|l|}{ Taste and flavour } \\
\hline Total intensity-F & The strength of all flavours in the product \\
\hline Sour-F & Related to a fresh, balanced flavour, which is due to organic acids \\
\hline Sweet-T & Related to the basic taste sweet (sucrose) \\
\hline Salty-T & Related to the basic taste salty $(\mathrm{NaCl})$ \\
\hline Acidic- $\mathrm{T}$ & Related to all acidic tastes (citric acid/acetic acid) \\
\hline Bitter-T & Related to the basic taste bitter (quinine/caffeine) \\
\hline Umami-T & Related to the basic taste umami (sodium glutamate) \\
\hline Cloying-F & Relates to a flew, non-fresh, watery flavour \\
\hline \multicolumn{2}{|l|}{ Texture - with finger } \\
\hline Firmness & Related to the force needed to push the bread curvature completely flat \\
\hline \multicolumn{2}{|l|}{ Texture-in the mouth } \\
\hline Hardness & Mechanical texture attribute related to the force needed to bite through the sample with the grinders \\
\hline Juiciness & $\begin{array}{l}\text { Surface textural property that describes liquid absorbed or emitted from a product. Perception of } \\
\text { water after } 4-5 \text { chews. }\end{array}$ \\
\hline Chewing resistance & $\begin{array}{l}\text { Mechanical texture attribute related to time and number of chews which is necessary to fine-tune the sample } \\
\text { ready for swallowing. }\end{array}$ \\
\hline Doughiness & $\begin{array}{l}\text { Mechanical structural attribute related to the effort required to atomize the product into a condition ready } \\
\text { for swallowing, related to a moderate level of doughiness. }\end{array}$ \\
\hline
\end{tabular}

The grain test weight is measured on a standard volume of grains $\left(0.5 \mathrm{dm}^{3}\right)$ with standard water content and is given as $\mathrm{kg} / \mathrm{hl}$. It gives information about kernel development and grain filling. Well-filled grains increase the test weight, and numbers approaching $80 \mathrm{~kg} / \mathrm{hl}$ indicate good grain filling. The milling industry usually demands a test weight of wheat above $75 \mathrm{~kg} / \mathrm{hl}$. The test weight is closely related with the proportion of flour after sieving, because less well-filled kernels have relatively more bran. The thousand grain weight (TGW) informs about the average grain size, and wheat cultivars have a different potential maximum grain size which typically varies from 30 to $45 \mathrm{mg}$ per grain.

For the baking industry, the starch quality (falling number), protein content and technical protein quality measured by sedimentation volume with SDS are important characteristics to assess if a batch of grains may be usable for bread making.

The falling number describes the ability of the starch to swell and absorb water within its complex structure.
Starch damage by amylase enzymes activated by the onset of grain germination will affect this ability. Starch quality is measured as Hagberg Falling Number (Perkin Elmer 2019). Wet and warm weather conditions after grain maturity in autumn may initiate pre-harvest sprouting and thereby cause poor starch quality and low falling numbers. The amylases activated by onset of germination will proceed the decomposition of starch during dough making. Hence, even a small batch of grains with low falling number (and high enzymatic activity) may reduce the baking quality of a large batch of wheat with high falling number. Norwegian milling industry demands a falling number $>200$ to accept wheat for bread making. Grain with values $<200$ may be treated (heated) to reduce enzyme activity or used for other products, but it is mostly used for feed.

The protein content is measured as Kjeldahl-N, and the total $\mathrm{N}$ is multiplied by 6.25 to derive the protein content, assuming a standard $\mathrm{N}$ concentration of $16 \%$ in grain proteins $(100 / 16=6.25)$. Total $\mathrm{N}$ in the grains was measured by near infrared transmittance with an Infratec 
Fig. 2 Relationship between the content of zinc $(\mathrm{Zn})$ and age of approval (1-118 years) in grains of 20 cultivars of spring wheat, grown at two sites in MidNorway in 2017

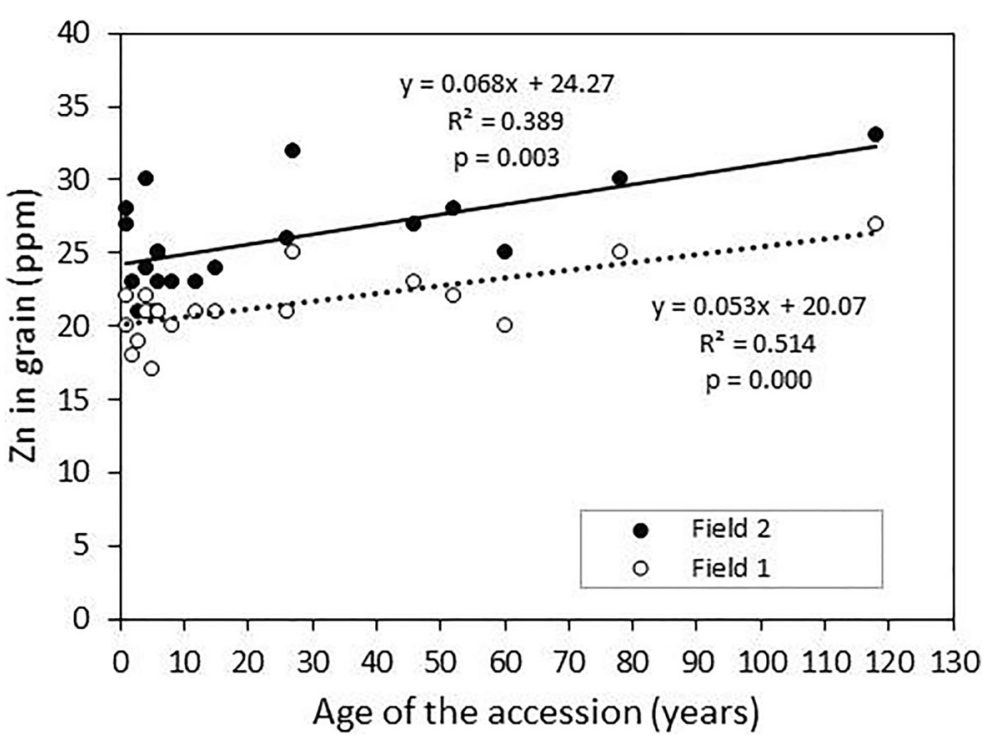

1241 Grain Analyzer (FOSS). The Norwegian milling industry demands at least $11.5 \%$ protein in wheat. Grain batches with lower protein levels are normally used for feed but may also be applicable for other purpose such as making porridge or flat bread.

Wheat grain batches with similar protein content may vary significantly in their ability to produce bread which raise efficiently and keep the form after baking (= baking quality). This is largely dependent on the protein quality, which is dependent both on the amount of gluten proteins in the total protein, and the ability of this gluten to construct a stable network which makes the bread stay risen after baking. Without such a network, carbon dioxide produced by the yeast during raising of the dough will emit, resulting in a heavy bread. Breeding wheat for industrial baking implies to foster the presence of some gluten components, whereas other components should be avoided. By modern industry baking, the dough must behave similarly over time, and it has to stand a tough mechanical processing. This has resulted in modern cultivars with "strong" gluten. For artisan baking, where the baker can get familiar with various batches of flour and adapt the practice to the characteristics in each case, cultivars with less strong gluten may be of high interest, especially if such cultivars can be tolerated by people not performing well with industrial bread products.

There are many rheological tests for measuring the bread making quality of flour, but such tests are usually time-consuming and demand costly equipment. There is a satisfactory and positive correlation between the fast
SDS-sedimentation method and industrial bread making quality with high mixing intensity. In the SDSsedimentation method, milled grains are mixed with water, lactic acid and sodium dodecyl sulphate (SDS) leading to the name SDS-test. The volume of precipitated material (sediment) is recorded. Proteins from grains with strong gluten components will swell more, and hence derive a higher volume of sediment. However, the volume will also increase with a higher content of protein. Hence, specific SDS values (SDS divided by the protein content) can provide additional information about the gluten quality.

For analyses of minerals, a composite sample of $200 \mathrm{~g}$ dry grains, $100 \mathrm{~g}$ per replicate plot, was made for each of the 20 selected lines from both sites in 2017 . The samples were shipped to Actlabs, Canada, to measure the concentrations of $\mathrm{P}, \mathrm{K}, \mathrm{Ca}, \mathrm{Mg}, \mathrm{S}, \mathrm{Na}, \mathrm{Fe}, \mathrm{Co}$, $\mathrm{Cu}, \mathrm{Mn}, \mathrm{Mo}, \mathrm{Se}$ and $\mathrm{Zn}$. The laboratory milled the grains and extracted the minerals by strong acids. Then, the concentrations of Co, Mo and Se were measured by inductively coupled plasma mass spectrometry (ICP-MS), and other minerals recorded by inductively coupled plasma optical emission spectrometry (ICPOES). To study the relationship between "age" of a line and the mineral concentrations, each line was assigned a number computed as 2018 minus the year of approval or, for not yet qualified lines, the year they were entering testing. For the land race Dala landhvete, the year of approval was set to 1900 , and the age $=118$. For GN lines, the year of entering is indicated by the first two digits in the line number, e.g. GN06557 was first tested 
in 2006 and received the age of $2018-2006=12$. For each mineral, the relationship between concentration and age at each growing site was computed.

Similarly, composite samples of grains from both experimental sites grown in 2017 from the 20 selected cultivars were used to produce flour and sourdough breads, which were assessed for quality. The 40 samples (cultivar $\times$ site) were treated anonymously. The assessment of how well the grain samples performed for artisan sourdough bread baking was conducted by Caroline Lindö in Sweden between April 3 and May 31, 2018. Caroline holds a PhD in microbiology and is a very experienced artisan baker. The grains were milled into flour using a KoMo Fidibus XL table-sized stone mill, the same day as the test baking occurred. After milling, the flour was sieved through a sieving cloth, where about $85 \%$ of the particles passed the cloth. The amount of gluten proteins was measured by washing out the starch from samples of dough prepared from $10 \mathrm{~g}$ of flour. Remains after washing are gluten proteins. The remains were assessed for stability, elasticity and extensibility, with results presented in Løes et al. (2019). For bread baking, $300 \mathrm{~g}$ of non-sieved flour, $300 \mathrm{~g}$ of sieved flour, $80 \mathrm{~g}$ sourdough culture and $14 \mathrm{~g}$ salt were mixed with an appropriate amount of water, and the water volume was recorded. The dough was mixed by hand and set in room temperature with careful stretching and folding once per hour to level out the temperature and strengthen the gluten. When assessed ready for further treatment, the dough was divided in two, loaves of bread were formed and put in small baskets overnight in refrigerator. Next day, the bread was baked in an electric oven with a stone plate, with a temperature between 240 and $270{ }^{\circ} \mathrm{C}$. After baking, the form, colour, crust and odour of each bread was assessed. After cooling, one bread was cut in two to assess the structure, elasticity, colour and odour of the crumb (the inside of the bread). Then, the bread was tasted, and a photograph was taken of the grains, the complete bread and the crumb (see Løes et al. 2019). Several evaluation criteria were merged into a value between 1 (least good bread, raw, with poor raising, not keeping the initial spherical form well) and 5 (best bread, well baked, well raised and keeping the form).

Six bread loaves from growing site 2, which all received a character of 3 or better, were selected for sensory analysis at Nofima AS in Ås, Norway. The selected cultivars comprised the old cultivar Fram II, the early bred cultivar Runar, two Swedish cultivars
Polkka and Sport and modern cultivars Mirakel and Seniorita. The test was conducted on June 27, 2018. To describe the objective perception of the various samples, a trained panel performed a Quality Descriptive Analysis, ISO 13299:2016(E) of each bread loaf (ISO 2016). The panel consisted of 10 subjects employed exclusively to work as sensory assessors at Nofima. Assessors are selected on the basis of their sensory qualities. Each of the 10 members take part in sensory analyses $12 \mathrm{~h}$ per week and has an average of 15 years of experience using descriptive analysis on various kinds of food and beverages including bread. The panellists have been selected and trained according to recommendations in ISO 8586:2012(E) (ISO 2012). The sensory laboratory has been designed according to guidelines in ISO 8589:2007(E) with separate booths and electronic registration of data (Eye Question, Logic 8 , Nederland), standardised light and a separate ventilation system (ISO 2007).

The aim of this study was to describe objectively possible differences in sensory attributes between the six bread loaves, from 16 characteristics being observed. Prior to the assessments, two samples (Polkka, Mirakel) were applied in a training session to agree on the variation in attribute intensity. The results from the training session were reviewed by a profile plot, using the software Panel Check for a visual performance monitoring. The output of this session was a list of attributes which comprised odour, flavour/taste and texture (Table 4).

The bread loaves were sent frozen overnight from Sweden to Nofima and after thawing they were heated in a baking oven for $10 \mathrm{~min}$ at $200{ }^{\circ} \mathrm{C}$ to allow for the aroma of the breads to develop. After cooling, even slices were cut in a bread slicing machine, and standardised pieces for testing were taken by cutting circles with a diameter of $22 \mathrm{~mm}$ from the medium slices of the loaves. For each bread, each panellist received two circles of the inner part of the bread (crust excluded), keeping room temperature. The two pieces were used to assess odour. Thereafter, one piece was used to assess flavour/taste, and the other to assess texture. For neutralization of the mouth, the panellists were required to rinse with lukewarm water and unsalted crackers between samples. The limited amount of bread complicated the study because it was a challenge for the sensory panel to catch all nuances with the small pieces available. The coded samples were served in blind trials randomized according to sample, assessor and replicate. The bread was served to the assessors in 
white plastic cups with a three-digit code, covered by a lid. The panellists evaluated the samples in duplicate, during four sessions with at least 15 min break between each session. The assessors recorded their results at individual speed on a $15 \mathrm{~cm}$ non-structured continuous scale with the left side of the scale corresponding to the lowest intensity and the right side corresponding to the highest intensity. The computer transformed the responses into numbers between $1=$ no intensity and $9=$ distinct intensity.

\section{Results}

Grain yield and quality

Due to the weather conditions during the growing seasons, the cereal yields were quite high in 2017, but very low in 2018 (Table 5). In 2017, cold weather enhanced growth during early growing season, and a warm and dry autumn contributed to acceptable yields with good grain quality. In 2018, summer drought and high precipitation in autumn resulted in low yields and poor grain quality. However, the field experiments produced reliable results in both years, which allows for assessing the performance of the different lines in two very different growing seasons.

There was no strong relationship between grain yields in the two growing seasons. Two modern cultivars Mirakel and GN16503 gave the highest yields in both growing seasons, about 3.6 tons per hectare (ha) in 2017 (Table 5). The old cultivars Dala Landhvete and Fram II gave about $30 \%$ less yields (around 2.5 tons per ha), but Norrøna and Møystad performed remarkably well in 2017 and yielded about 3.5 tons. In the challenging year of 2018, all cultivars yielded below 2 tons per ha on average. The old cultivars performed better than several modern cultivars in that year, but the differences were insignificant. Runar, which was the earliest cultivar in our study, matured 5 days before Mirakel and yielded on average 3.31 tons of grains (15\% water content) ha ${ }^{-1}$ in 2017.

The poor growing conditions in 2018 was also reflected in a considerably lower test weight (Table 6), 71 (kg per hectolitre) as compared with 81.3 in 2017 , indicating a poor grain filling, especially at site 2 where the drought had even more negative effects than at site 1 with lighter soil (Table 1). This is also shown by the very short mean straw length at this site in 2018 , only
$65 \mathrm{~cm}$ (Table 5), whereas the length was $74 \mathrm{~cm}$ at site 1 and more than $90 \mathrm{~cm}$ at both sites in 2017. The kernels were also smaller in 2018 than in 2017 (thousand grain weight (TGW), Table 6).

The old cultivars had smaller kernels, with poorer grain filling than modern cultivars (Table 6). Across sites and years, the four cultivars approved before 1970 had a TGW of $29.6 \mathrm{~g}$. The other 21 cultivars had a mean TGW of $33.3 \mathrm{~g}$. Long and weak straw resulted in significant lodging in the oldest cultivars in both years (Table 5). This is a very clear difference between old and modern cultivars. As shown by low falling numbers (Table 6), even in 2017 the old cultivars were susceptible to preharvest sprouting damage, which was increased by lodging. In 2018, many cultivars had very low falling numbers, due to the extremely wet harvest conditions.

Breeding for increased grain yield tends to reduce the protein concentration, which was also found in our study. In general, the lower yielding old cultivars had higher protein content than the modern cultivars (Table 6), but lower protein yield.

The SDS-sedimentation volumes were considerably higher in 2018 , on average $70 \mathrm{~cm}^{3}$ as compared with 58 in 2017. The values are somewhat lower than reported by Åssveen et al. (2017) in a study from Southern Norway of conventionally grown spring wheat during 2015-2017. These authors found SDS values around 90 for Mirakel and Seniorita, likely due to better climatic conditions and higher application of fertiliser. On average across sites and years, the four old varieties had SDS-sedimentation volumes of $45 \mathrm{~cm}^{3}$, while the mean of the other 21 lines was $65 \mathrm{~cm}^{3}$. This confirms that modern cultivars have different gluten characteristics from old cultivars. No correlation was found between protein content and SDS value for each site and year, but a positive correlation $\left(r^{2}=0.47\right)$ was found for the average values over four experiments (Løes et al. 2019).

Based on an overall assessment of the tested lines, GN03503, GN14649 and GN16503 are interesting for further testing with organic growing conditions in this region. They have stable high yields, low falling numbers and good grain quality characteristics. Among the tested current market varieties, Mirakel performed better than Seniorita, which is shorter and may compete less well with weeds. Runar is an interesting variety which could be considered for being brought back to practical use in organic growing, due to earliness, long straw and good performance, at least in the season with good conditions for cereal growing. 
Table 525 cultivars of spring wheat listed by year of approval, with grain yields at $15 \%$ moisture, moisture at harvest, straw length, lodging and earliness recorded as days required for yellow ripening relative to Mirakel (negative values = earlier ripening).
Values are means of two replicates at two sites in each year. Values for coefficients of variation $(\mathrm{CV})$ and least significant differences (LSD) are included in the table $(p<0.05)$

\begin{tabular}{|c|c|c|c|c|c|c|c|c|c|}
\hline \multirow[b]{2}{*}{ Cultivar } & \multicolumn{2}{|c|}{ Yield, kg/ha } & \multicolumn{2}{|c|}{ Moisture, \% } & \multicolumn{2}{|c|}{ Straw length, cm } & \multicolumn{2}{|c|}{ Lodging, \% } & \multirow{2}{*}{$\begin{array}{l}\text { Ripening, days } \\
2017 / 2018\end{array}$} \\
\hline & 2017 & 2018 & 2017 & 2018 & 2017 & 2018 & 2017 & $2018^{*}$ & \\
\hline Dala landhvete & 2340 & 1580 & 29.4 & 36.8 & 114 & 93 & 99 & 60 & -2 \\
\hline Fram II (1940) & 2630 & 1470 & 29.3 & 41.4 & 113 & 82 & 100 & 100 & -4 \\
\hline Norrøna (1952) & 3510 & 1590 & 21.9 & 38.1 & 105 & 84 & 43 & 63 & -3 \\
\hline Møystad (1967) & 3420 & 1540 & 22.1 & 40.4 & 105 & 81 & 70 & 63 & -4 \\
\hline Runar (1972) & 3310 & 1640 & 19.0 & 37.4 & 99 & 72 & 1 & 3 & -5 \\
\hline Polkka (1992) & 3310 & 1740 & 17.0 & 35.2 & 89 & 74 & 3 & 0 & -2 \\
\hline Sport (1994) & 2990 & 1540 & 18.8 & 35.5 & 95 & 72 & 1 & 0 & -3 \\
\hline Mirakel (2012) & 3550 & 1980 & 24.2 & 36.3 & 98 & 71 & 4 & 3 & 0 \\
\hline GN03503 & 3250 & 1900 & 23.5 & 36.8 & 92 & 69 & 0 & 3 & -2 \\
\hline Seniorita (2014) & 3110 & 1490 & 20.9 & 35.6 & 87 & 66 & 25 & 10 & 0 \\
\hline GN06557 & 3690 & 1630 & 21.6 & 37.3 & 84 & 65 & 4 & 0 & -3 \\
\hline GN10603 & 3270 & 1710 & 21.3 & 35.4 & 86 & 66 & 0 & 8 & 0 \\
\hline GN12634 & 2820 & 1670 & 23.0 & 37.7 & 90 & 68 & 1 & 25 & -1 \\
\hline GN12741 & 3360 & 1450 & 29.6 & 38.7 & 81 & 64 & 1 & 5 & 1 \\
\hline GN12759 & 3020 & 1570 & 23.3 & 36.4 & 90 & 70 & 0 & 0 & -1 \\
\hline GN12760 & 2950 & 1640 & 17.8 & 39.4 & 84 & 63 & 0 & 0 & -3 \\
\hline GN13618 & 3340 & 1860 & 22.4 & 34.5 & 82 & 70 & 5 & 0 & 0 \\
\hline GN14529 & 2880 & 1660 & 20.6 & 35.1 & 86 & 73 & 0 & 0 & -1 \\
\hline GN14649 & 3070 & 1710 & 22.7 & 34.3 & 84 & 61 & 0 & 1 & -2 \\
\hline GN15621 & 3360 & 1590 & 24.8 & 38.2 & 86 & 64 & 3 & 15 & 1 \\
\hline GN16503 & 3570 & 1910 & 24.9 & 33.7 & 90 & 74 & 1 & 3 & 1 \\
\hline GN17632 & 3030 & 1680 & 21.0 & 36.0 & 88 & 65 & 0 & 0 & 0 \\
\hline GN17633 & 3240 & 1750 & 26.0 & 40.9 & 90 & 68 & 0 & 2 & 1 \\
\hline GN17634 & 2940 & 1380 & 23.1 & 38.8 & 82 & 62 & 0 & 0 & -1 \\
\hline GN17635 & 3290 & 1360 & 19.7 & 38.0 & 92 & 72 & 4 & 8 & -2 \\
\hline Mean site 1 & 2690 & 2240 & 23.9 & 40.7 & 93 & 74 & 13 & 0 & \\
\hline Mean site 2 & 3640 & 1040 & 21.4 & 33.5 & 90 & 65 & 16 & 15 & \\
\hline Grand mean & 3170 & 1640 & 22.7 & 37.1 & 92 & 70 & 14 & 15 & \\
\hline $\mathrm{CV}$ & 4.5 & 8.4 & 7.1 & 10.3 & 2 & 8 & 101 & 98 & \\
\hline LSD & 270 & 190 & 3.0 & 5.4 & 4 & 8 & 25 & 25 & \\
\hline
\end{tabular}

* No lodging in site 2 in 2018

Grain mineral concentrations

The concentration of both selenium and cobalt was below $1 \mathrm{mg} \mathrm{kg}^{-1}$ in all grain samples analysed $(n=$ 40). This may seem negative, since selenium is an essential micronutrient for humans and animals which often needs supplementation (Haug et al. 2007). However, concentrations well below $1 \mathrm{mg} \mathrm{kg}^{-1}$ of these minerals in cereals are to be expected (see e.g. DíazAlarcón et al. 1996; MacPherson and Dixon 2003), and if these minerals had been of special interest in our study, we would have had to use another laboratory package with lower limit of detection.

For other minerals, we found statistically significant relationships $(p<0.01)$ between concentration and "age" of the cultivars for zink ( $\mathrm{Zn})$, iron $(\mathrm{Fe})$ and $\mathrm{P}$. 
Table 6 Quality characteristics test weight (TW), thousand grain weight (TGW), falling number (FN), protein content, SDSsedimentation volume and specific SDS. Mean values over two sites in 2017 and 2018. The baking quality of grain from site 1 and 2 in 2017 is given as number from 1 to 5 , where $1=$ least good and $5=$ best

\begin{tabular}{|c|c|c|c|c|c|c|c|c|c|c|c|c|c|c|}
\hline \multirow[t]{2}{*}{ Variety/Accession } & \multicolumn{2}{|c|}{$\mathrm{TW}, \mathrm{kg} \mathrm{hl}^{-1}$} & \multicolumn{2}{|c|}{ TGW, g } & \multicolumn{2}{|c|}{$\mathrm{FN}, \mathrm{s}$} & \multicolumn{2}{|c|}{ Protein, $\%$} & \multicolumn{2}{|c|}{ SDS, $\mathrm{cm}^{3}$} & \multicolumn{2}{|c|}{ Specific, SDS } & \multicolumn{2}{|c|}{ Baking quality } \\
\hline & 17 & 18 & 17 & 18 & 17 & 18 & 17 & 18 & 17 & 18 & 17 & 18 & 1 & 2 \\
\hline Dala landhvete & 77.9 & 72.6 & 33.8 & 29.8 & 148 & 104 & 13.0 & 13.9 & 42 & 58 & 3.2 & 4.2 & 2 & 1 \\
\hline Fram II & 76.6 & 71.4 & 29.3 & 25.8 & 209 & 150 & 12.7 & 14.3 & 30 & 48 & 2.4 & 3.4 & 2 & 3 \\
\hline Norrøna & 77.8 & 68.5 & 31.8 & 26.5 & 194 & 71 & 10.1 & 12.2 & 45 & 57 & 4.5 & 4.7 & 2 & 2 \\
\hline Møystad & 78.1 & 70.6 & 30.0 & 29.9 & 200 & 64 & 11.1 & 13.3 & 34 & 50 & 3.1 & 3.8 & 2 & 1 \\
\hline Runar & 79.8 & 74.1 & 40.1 & 28.3 & 288 & 97 & 11.1 & 13.9 & 53 & 69 & 4.8 & 5.0 & 4 & 5 \\
\hline Polkka & 78.5 & 73.1 & 37.4 & 28.9 & 287 & 74 & 11.3 & 12.6 & 57 & 62 & 5.0 & 4.9 & 4 & 4 \\
\hline Sport & 80.2 & 73.8 & 31.0 & 26.9 & 203 & 65 & 13.7 & 14.8 & 62 & 72 & 4.5 & 4.9 & 1 & 3 \\
\hline Mirakel & 79.3 & 72.0 & 39.1 & 30.4 & 292 & 155 & 11.2 & 12.8 & 75 & 79 & 6.7 & 6.2 & 5 & 4 \\
\hline GN03503 & 79.2 & 73.8 & 39.5 & 32.1 & 288 & 189 & 11.2 & 13.4 & 59 & 74 & 5.3 & 5.5 & 4 & 4 \\
\hline Seniorita & 79.5 & 73.6 & 32.3 & 27.7 & 285 & 148 & 11.6 & 13.2 & 64 & 73 & 5.5 & 5.5 & 5 & 5 \\
\hline GN06557 & 78.7 & 72.8 & 36.7 & 29.4 & 336 & 170 & 10.6 & 12.5 & 66 & 77 & 6.2 & 6.2 & 1 & 4 \\
\hline GN10603 & 80.1 & 72.7 & 36.1 & 27.3 & 289 & 147 & 11.3 & 14.0 & 54 & 71 & 4.8 & 5.1 & 5 & 4 \\
\hline GN12634 & 80.0 & 74.0 & 37.6 & 28.6 & 366 & 208 & 12.4 & 14.3 & 63 & 80 & 5.1 & 5.6 & - & - \\
\hline GN12759 & 79.6 & 74.2 & 36.3 & 29.8 & 383 & 197 & 11.4 & 13.7 & 67 & 78 & 5.9 & 5.7 & 5 & 5 \\
\hline GN12760 & 79.5 & 73.2 & 37.8 & 28.8 & 376 & 157 & 10.9 & 14.0 & 67 & 80 & 6.1 & 5.7 & 3 & 5 \\
\hline GN13618 & 78.7 & 73.5 & 37.3 & 33.0 & 296 & 97 & 10.8 & 11.9 & 72 & 76 & 6.7 & 6.4 & 3 & 4 \\
\hline GN14529 & 79.7 & 73.2 & 43.3 & 35.6 & 292 & 240 & 12.0 & 13.8 & 64 & 72 & 5.3 & 5.2 & - & - \\
\hline GN14649 & 80.8 & 74.4 & 39.0 & 32.3 & 331 & 209 & 11.5 & 13.0 & 65 & 79 & 5.7 & 6.1 & 5 & 5 \\
\hline GN15621 & 80.3 & 72.5 & 34.6 & 28.6 & 288 & 134 & 10.8 & 12.4 & 68 & 74 & 6.3 & 6.0 & 3 & 3 \\
\hline GN16503 & 78.6 & 74.1 & 37.8 & 32.0 & 290 & 174 & 10.7 & 11.5 & 62 & 68 & 5.8 & 5.9 & 5 & 5 \\
\hline GN17632 & 79.2 & 72.4 & 39.6 & 30.7 & 250 & 174 & 11.0 & 13.5 & 64 & 73 & 5.8 & 5.4 & 3 & 3 \\
\hline GN17633 & 81.1 & 74.8 & 37.0 & 28.3 & 270 & 201 & 11.5 & 14.2 & 61 & 82 & 5.3 & 5.8 & - & - \\
\hline GN17634 & 79.5 & 71.2 & 34.6 & 25.3 & 150 & 98 & 11.8 & 13.7 & 55 & 65 & 4.7 & 4.7 & - & - \\
\hline GN17635 & 80.3 & 74.8 & 34.7 & 28.9 & 339 & 114 & 11.5 & 13.0 & 51 & 65 & 4.4 & 5.0 & 4 & 5 \\
\hline Mean site 1 & 79.2 & 74.4 & 36.3 & 33.7 & 276 & 100 & 11.0 & 12.7 & 58 & 73 & 5.3 & 5.8 & 3.40 & \\
\hline Mean site 2 & 79.4 & 71.6 & 35.8 & 25.2 & 282 & 185 & 11.8 & 13.9 & 58 & 67 & 5.0 & 4.9 & 3.75 & \\
\hline Grand mean & 81.3 & 73.0 & 36.1 & 29.4 & 279 & 143 & 11.4 & 13.3 & 58 & 70 & 5.1 & 5.3 & & \\
\hline $\mathrm{CV}$ & 0.6 & 2.0 & 3.9 & 9.2 & & & 2.7 & 7.7 & 3.6 & 7.7 & 19.1 & 5.9 & & \\
\hline LSD & 0.9 & 2.5 & 2.4 & 4.6 & & & 0.5 & 1.8 & 3.6 & 9.2 & 1.6 & 0.6 & & \\
\hline
\end{tabular}

For $\mathrm{Zn}, 39-51 \%$ of the variation was explained by "age" (Fig. 2). For Fe, variation of "age" explained 33-68\% of the variation in grain concentration, and for $\mathrm{P}$ it explained 39-42\% (Løes et al. 2019). For other minerals tested ( $\mathrm{S}, \mathrm{K}, \mathrm{Mg}, \mathrm{Ca}, \mathrm{Na}, \mathrm{Cu}, \mathrm{Mo}$ ), the relationship with "age" was less clear than for $\mathrm{P}, \mathrm{Fe}$ and $\mathrm{Zn}$.

The sum of all minerals analysed except total $\mathrm{N}$ showed a significant and negative relationship with the mean grain yield across growing sites (Fig. 3). The variation in grain yield explained about $42 \%$ of the variation in accumulated minerals. This demonstrates the dilution effect of minerals in modern lines of spring wheat.

Baking quality and sensory analyses

An important, overall result from the baking test was that fully edible and palatable breads were produced from all the 40 grain samples. Ten percent of the 40 bread loaves received score $1,15 \%$ score $2,20 \%$ score $3,23 \%$ score 4 and $32 \%$ score 5 , where 5 was given to the overall best bread. 
Fig. 3 Relationship between accumulated mineral content (P, K, Ca, Mg, S, Na, Fe, Co, Cu, $\mathrm{Mn}, \mathrm{Mo}, \mathrm{Se}$ and $\mathrm{Zn}$ ) and mean grain yield for 20 cultivars of spring wheat grown at two sites in Mid-Norway in 2017

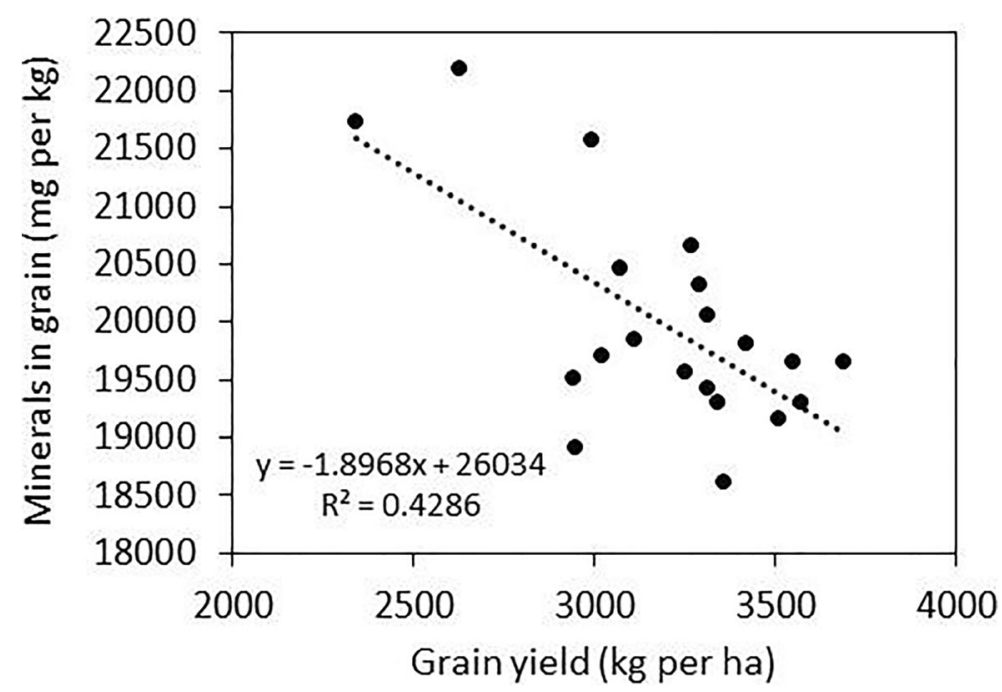

Discussion

However, there were some interesting differences, and the modern cultivars Seniorita and Mirakel, some breeding lines and Runar achieved the best overall evaluations (Table 6). The old cultivars had much lower SDS values (45 or below), whereas modern cultivars had 51 or above. Concurrently, the old cultivars scored only $1-3$ in the baking test at both sites.

Since only a restricted number of sensory analyses could be conducted, we agreed to send bread loaves from cultivars which received a character of 3 or higher at both sites, hence excluding bread from the oldest cultivars. The sensory analyses were performed on bread made from each of the six cultivars Runar, Fram II, Seniorita, Mirakel, Polkka and Sport, grown at site 2 in 2017. Significant differences were found above all for odour and texture, but only for one flavour/taste attribute, acidic taste (Fig. 4; Tables 7 and 8). The bread made of Polkka had considerably less acidic taste than the bread loaves of the other cultivars, where the acidic taste was quite similar. The bread made of Seniorita had both the most distinct vinegar odour, the highest total odour intensity and the highest mean value for acidic taste. Bread from Mirakel had a significantly weaker vinegar odour than Seniorita. The two Swedish cultivars Polkka and Sport were significantly firmer and harder than all Norwegian cultivars. Fram II, Runar and Seniorita also had a lower chewing resistance than Mirakel, Polkka and Sport. Another obvious difference was the juiciness, where bread from Runar was most juicy, and Polkka the least juicy. Bread loaves from the two Swedish cultivars were less juicy than bread from the four Norwegian cultivars.
The main aim of this study was to increase the diversity of cultivars used for growing of organic cereals, by searching for modern cultivars possibly performing well under organic growing conditions in Mid-Norway, and with artisan baking. Our assessments, of agronomic traits, grain quality, baking quality and sensory attributes revealed that modern cultivars yield more grains, have stronger straw, less risk for lodging and pre-harvest sprouting damage and better grain quality. This result is in agreement with several other studies of breeding progress in spring wheat. For 10 Finnish wheat cultivars released in 1939-1990, grain yield increased by $20 \%$ with $7 \%$ reduction in straw length and $80 \%$ improvement in lodging resistance in the most recent cultivars (Peltonen-Sainio and Peltonen 1994). For 316 winter wheat varieties studied in Germany, the increase in grain yield from 1983 to 2014 was $24 \%$, and the protein concentration declined by $8 \%$ in the same period (Laidig et al. 2017). On average, a lower protein concentration in modern cultivars was also found in the present study, but the variation was high (10.7-12.4\% in 2017). Due to higher yields, the protein yield will normally be higher in modern cultivars. For 16 Italian winter wheat varieties released between 1900 and 1994, grown with different $\mathrm{N}$ application, again a significant yield gain with modern cultivars was confirmed, estimated to be $33.5 \mathrm{~kg}$ per hectare and year (Guarda et al. 2004). These authors also found a decreasing protein concentration over time, being $0.03 \%$ per year. However, the total grain uptake of $\mathrm{N}$ increased with 


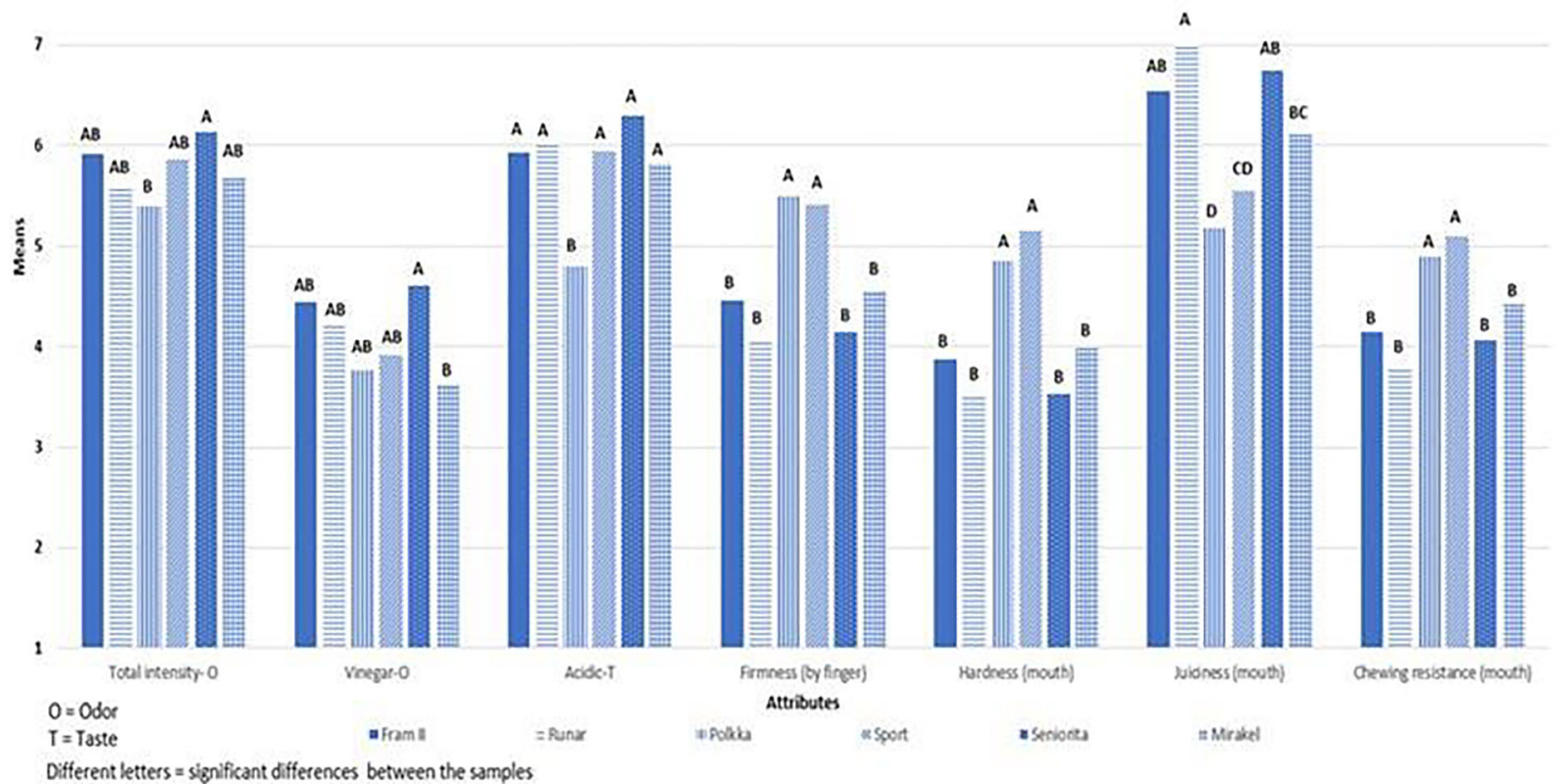

Fig. 4 Mean values of sensory attributes where statistically significant differences were found in sourdough bread from 6 cultivars of spring wheat grown in a field trial in 2017. For each

increasing $\mathrm{N}$ application, but also increased significantly in modern cultivars, irrespective of $\mathrm{N}$ application. The most recent cultivars gave 13,37 and $43 \%$ more protein per hectare with application of zero, 80 or $160 \mathrm{~kg} \mathrm{~N}$ per

Table 7 Mean values for odour and texture of sourdough bread from six spring wheat cultivars. Each scale goes from 1 to 9, where $1=$ no intensity and $9=$ distinct intensity. For each attribute, values attribute, cultivars with different letters (A, B, C, D) assigned are significantly different $(p<0.05)$

hectare, when compared with the oldest. These authors conclude that even with restricted $\mathrm{N}$ application, which may occur in organic growing, modern cultivars will give best yield and best grain quality.

with different letters assigned (A, B, C, D) are significantly different by Tukey's test method

\begin{tabular}{|c|c|c|c|c|c|c|c|c|}
\hline & \multicolumn{3}{|l|}{ Odour } & \multicolumn{5}{|l|}{ Texture } \\
\hline & Total intensity & Sour & Vinegar & Firmness $^{\mathrm{a}}$ & Hardness $^{\mathrm{b}}$ & Juiciness $^{\mathrm{b}}$ & Chewing resistance ${ }^{b}$ & Doughiness $^{\mathrm{b}}$ \\
\hline Fram II & $5.92 \mathrm{AB}$ & $4.37 \mathrm{~A}$ & $4.44 \mathrm{AB}$ & $4.46 \mathrm{~B}$ & $3.88 \mathrm{~B}$ & $6.55 \mathrm{AB}$ & $4.15 \mathrm{~B}$ & $4.22 \mathrm{~A}$ \\
\hline Runar & $5.58 \mathrm{AB}$ & $4.25 \mathrm{~A}$ & $4.22 \mathrm{AB}$ & $4.04 \mathrm{~B}$ & $3.50 \mathrm{~B}$ & $7.02 \mathrm{~A}$ & $3.79 \mathrm{~B}$ & $4.59 \mathrm{~A}$ \\
\hline Polkka & $5.40 \mathrm{~B}$ & $3.92 \mathrm{~A}$ & $3.77 \mathrm{AB}$ & $5.50 \mathrm{~A}$ & $4.86 \mathrm{~A}$ & $5.18 \mathrm{D}$ & $4.90 \mathrm{~A}$ & $4.24 \mathrm{~A}$ \\
\hline Sport & $5.86 \mathrm{AB}$ & $3.88 \mathrm{~A}$ & $3.91 \mathrm{AB}$ & $5.41 \mathrm{~A}$ & $5.15 \mathrm{~B}$ & $5.55 \mathrm{CD}$ & $5.10 \mathrm{~A}$ & $4.36 \mathrm{~A}$ \\
\hline Seniorita & $6.13 \mathrm{~A}$ & $4.21 \mathrm{~A}$ & $4.61 \mathrm{~A}$ & $4.15 \mathrm{~B}$ & $3.54 \mathrm{~B}$ & $6.75 \mathrm{AB}$ & $4.07 \mathrm{~B}$ & $4.38 \mathrm{~A}$ \\
\hline Mirakel & $5.67 \mathrm{AB}$ & $4.39 \mathrm{~A}$ & $3.63 \mathrm{~B}$ & $4.55 \mathrm{~B}$ & $3.98 \mathrm{~B}$ & $6.11 \mathrm{BC}$ & $4.42 \mathrm{AB}$ & $4.49 \mathrm{~A}$ \\
\hline$p$ value & 0.023 & 0.523 & 0.017 & $<0.001$ & $<0.001$ & $<0.001$ & $<0.001$ & 0.776 \\
\hline
\end{tabular}

${ }^{\mathrm{a}}$ By finger

${ }^{\mathrm{b}}$ In the mouth 
Table 8 Mean values for taste of sourdough bread from six spring wheat cultivars. Each scale goes from 1 to 9 , where $1=$ no intensity and $9=$ distinct intensity. For each attribute, values with different letters assigned are significantly different by Tukey’s test method

\begin{tabular}{|c|c|c|c|c|c|c|c|c|}
\hline & Total taste intensity & Sour & Sweet & Salty & Acidic & Bitter & Umami & Cloying \\
\hline Fram II & $5.97 \mathrm{~A}$ & $4.36 \mathrm{~A}$ & $2.44 \mathrm{~A}$ & $4.89 \mathrm{~A}$ & $5.93 \mathrm{~A}$ & $4.30 \mathrm{~A}$ & $2.15 \mathrm{~A}$ & $1.94 \mathrm{~A}$ \\
\hline Runar & $5.88 \mathrm{~A}$ & $4.49 \mathrm{~A}$ & $2.31 \mathrm{~A}$ & $4.88 \mathrm{~A}$ & $6.03 \mathrm{~A}$ & $4.37 \mathrm{~A}$ & $1.96 \mathrm{~A}$ & $1.84 \mathrm{~A}$ \\
\hline Polkka & $5.42 \mathrm{~A}$ & $3.50 \mathrm{~A}$ & $2.27 \mathrm{~A}$ & $4.38 \mathrm{~A}$ & $4.80 \mathrm{~B}$ & $4.50 \mathrm{~A}$ & $1.87 \mathrm{~A}$ & $2.54 \mathrm{~A}$ \\
\hline Sport & $6.14 \mathrm{~A}$ & $4.25 \mathrm{~A}$ & $2.29 \mathrm{~A}$ & $4.96 \mathrm{~A}$ & $5.95 \mathrm{~A}$ & $4.59 \mathrm{~A}$ & $2.04 \mathrm{~A}$ & $1.66 \mathrm{~A}$ \\
\hline Seniorita & $6.00 \mathrm{~A}$ & $4.34 \mathrm{~A}$ & $2.52 \mathrm{~A}$ & $4.74 \mathrm{~A}$ & $6.30 \mathrm{~A}$ & $4.16 \mathrm{~A}$ & $2.04 \mathrm{~A}$ & $1.94 \mathrm{~A}$ \\
\hline Mirakel & $5.81 \mathrm{~A}$ & $4.48 \mathrm{~A}$ & $2.50 \mathrm{~A}$ & $4.59 \mathrm{~A}$ & $5.82 \mathrm{~A}$ & $4.19 \mathrm{~A}$ & $2.04 \mathrm{~A}$ & $1.73 \mathrm{~A}$ \\
\hline$p$ value & 0.091 & 0.094 & 0.266 & 0.342 & $<0.001$ & 0.403 & 0.750 & 0.077 \\
\hline
\end{tabular}

The lower concentration of minerals in modern cultivars found here was in line with results of Fan et al. (2008) and Zhao et al. (2009). For Zn, which was the mineral where the effect of age was most evident also in these referred studies, the difference between the lowest concentration (found at both sites in GN13618) and the highest (at both sites in Dala Landhvete) was more than $10 \mathrm{mg} / \mathrm{kg}$ (Løes et al. 2019). However, for all recorded minerals except sodium $(\mathrm{Na})$ and manganese $(\mathrm{Mn})$, there was a significant effect of growing site. As shown in Fig. 2 for $\mathrm{Zn}$, the concentrations were higher at site 2, with more clay in the soil (Table 1). For Zn, the effect of growing site comprised about $5 \mathrm{mg}$ per $\mathrm{kg}$ grain.

As shown in the present study, modern cultivars also perform well with artisan baking, whereas old cultivars gave bread with less favourable characteristics. For bread from six cultivars, we also found a significant effect of genotype (cultivar) on sensory attributes. One former study also combined baking test with sensory analysis of wheat products (Kucek et al. 2017). These authors studied altogether 16 wheat cultivars used for making sourdough and/or yeast bread, cookies, pasta and cooked grain. Interestingly, the ranking of cultivars differed among products. For example, one variety performing well for crackers was the poorest for making cookies, and one cultivar performing poorly for sourdough bread was not the poorest for making yeast bread. Similarly, intense flavour in cooked grain (which is requested) was not linked with intense flavour when the same cultivar was used for sourdough bread, and one test panel which ranked one emmer cultivar highest when cooked ranked the same cultivar lowest when prepared as pasta. Hence, the authors conclude that to select the best cultivar depends on what type of product will be made from it.
The colour of the wheat bran (red or white) may also affect palatability of products made from the wheat. A French study showed that consumers there preferred the taste of red wheat cultivars (Vindras-Fouillet et al. 2014). In Norway, all spring wheat cultivars are red since white cultivars have a higher risk of pre-harvest sprouting, which is an important negative characteristic with Norwegian climatic conditions.

A study from New Zealand (Heenan et al. 2008) showed that positive drivers of fresh bread for consumers were porous appearance, floury odour, malty odour, toasted odour, sweet flavour and sweet aftertaste. For the breads in our study, there was no significant difference in sweet taste. Since the crust was not assessed, there was no toasted odour or flavour on the breads. But we know that most consumers prefer a juicy bread to a less juicy one. Since the Norwegian varieties were juicier than the Swedish cultivars, we would assume that consumers would appreciate these breads in terms of texture. They were also less hard and had less chewing resistance.

Overall, it should be of interest for organic farmers to grow modern cultivars, even for artisan baking. However, that seems not to be the case. Consumers' interest in old cultivars is high, after successful marketing and product development. The current price of flour from Dala Landhvete and spelt wheat in Norwegian web shops by March 2020 is NOK 40-50, which is 4-5 Euro. The price of $1 \mathrm{~kg}$ conventional wheat flour on the web (and in conventional shops) was NOK 13, about 1.3 Euro. In spite of this, we recommend expanding the number of varieties grown organically, and introducing new stories about some interesting varieties, e.g. Runar which is a successful example of early modern cereal breeding in Norway. 
Six varieties have been selected for a follow-up project during 2019-2021 (Dala landhvete, Runar, Mirakel, Seniorita, GN16503 and GN17635). With the aim of increasing the quality, and diversity, of organically grown grain seed, we will study how active selection of evenly large grain seeds by air-separation may affect seed quality. The project will inform about possibilities within national regulations to broaden the offer of cultivars for organic growing and disseminate knowledge on how to establish small-scale distribution of seed grains.

Acknowledgements We are grateful for the economic support from a program to protect genetic resources with the Norwegian Agriculture Agency, and from the County Governors of Oppland and Trøndelag. We also acknowledge the genetic material made available to this study from Graminor AS. The authors are grateful for the cooperation with local farmers, Torunn Hernes Bjerkem, Gjermund Haga and Ole Petter Riis, and for the skilled experimental work carried out by the Norwegian Agricultural Extension Service Trøndelag.

Funding Information Open Access funding provided by Norwegian Institute of Bioeconomy Research.

Open Access This article is licensed under a Creative Commons Attribution 4.0 International License, which permits use, sharing, adaptation, distribution and reproduction in any medium or format, as long as you give appropriate credit to the original author(s) and the source, provide a link to the Creative Commons licence, and indicate if changes were made. The images or other third party material in this article are included in the article's Creative Commons licence, unless indicated otherwise in a credit line to the material. If material is not included in the article's Creative Commons licence and your intended use is not permitted by statutory regulation or exceeds the permitted use, you will need to obtain permission directly from the copyright holder. To view a copy of this licence, visit http://creativecommons. org/licenses/by/4.0/.

\section{References}

Åssveen M, Tangsveen J, Weiseth L (2017) Sorter og sortsprøving 2017. NIBIO BOK 4(1):28-67. (In Norwegian)

Díaz-Alarcón JP, Navarro-Alarcón M, López-García de la Serrana H, López-Martínez MC (1996) Determination of selenium in cereals, legumes and dry fruits from southeastern Spain for calculation of daily dietary intake. Sci Total Environ 184: 183-189. https://doi.org/10.1016/0048-9697(96)05079-6

Egnèr MT, Riehm H, Domingo WR (1960). U ntersuchungen über die chemische Boden-Analyse als Grundlage für die Beurteilung des Nährstoffzustandes der Böden. II. Chemische Extraktionsmethoden zur Phosphor und Kaliumbestimmung. Kung. Lantbrukshögskolans Annaler 26: 199-215 (Studies of chemical soil analysis to assess the nutrient status of the soil. II. Chemical extractions of $\mathrm{P}$ and $\mathrm{K}$; in German)

Perkin Elmer (2019) The falling number method. https://www. perten.com/Products/Falling-Number/The-Falling-NumberMethod/. Accessed 17 Mar 2020

Eurofins (2020) Veiledning til jordanalyser (Assessment of soil analysis; in Norwegian). https://cdnmedia.eurofins. com/european-east/media/356784/veiledning-jord.pdf. Accessed 16 Mar 2020

Fan MS, Zhao FJ, Fairweather-Tait SJ, Poulton PR, Dunham SJ, McGrath SP (2008) Evidence of decreasing mineral density in wheat grain over the last 160 years. J Trace Elements Med Biol 22(4):315-324

Graminor (2020) About us. http://www.graminor.no/om-oss-enus/virksomhetsomrade-en-us/ . Accessed 24 Mar 2020

Guarda G, Padovan S, Delogu G (2004) Grain yield, nitrogen-use efficiency and baking quality of old and moder Italian breadwheat cultivars grown at different nitrogen levels. Eur $\mathrm{J}$ Agron 21:181-192. https://doi.org/10.1016/j. eja.2003.08.001

Haug A, Graham RD, Christophersen OA, Lyons GH (2007) How to use the world's scarce selenium resources efficiently to increase the selenium concentration in food. Microb Ecol Health D 19:209-228

Heenan SP, Dufour J, Hamid N, Harvey W, Delahunty CM (2008) The sensory quality of fresh bread: descriptive attributes and consumer perceptions. Food Res Int 41(10):989-997

ISO (2007) Sensory analyses -- General guidance for the design of test rooms. ISO 8589:2007, International organization for standardization, Geneve, Switzerland

ISO (2012) Sensory analyses --general guidance for the selection, training and monitoring of assessors - part 1: selected assessors. ISO 8586-1:2012

ISO (2016) Sensory analyses - Methodology - General guidance for establishing a sensory profile. ISO 13299:2016, International organization for standardization, Geneve, Switzerland

Kucek LK, Dyck E, Russell J, Clark L, Hamelman J, BurnsLeader S, Senders S, Jones J, Benscher D, Davis M, Roth G, Zwinger S, Sorrells ME, Dawson JC (2017) Evaluation of wheat and emmer varieties for artisanal baking, pasta making, and sensory quality. J Cereal Sci 74:19-27

Laidig F, Piepho HP, Rentel D, Drobek T, Meyer U, Huesken A (2017) Breeding progress, environmental variation and correlation of winter wheat yield and quality traits in German official variety trials and on-farm during 1983-2014. Theor Appl Genet 130:223-245. https://doi.org/10.1007/s00122016-2810-3

Lancashire PD, Bleiholder H, Vandenboom T, Langeluddeke P, Stauss R, Weber E, Witzenberger A (1991) A uniform decimal code for growth-stages of crops and weeds. Ann Appl Biol 119:561-601

Løes AK, Frøseth RB, Dieseth JA, Lindö C, Skaret J (2019) Kvalitetskorn til mat - muligheter i ikke-kommersialisert norsk sortsmateriale. Forsøk med vårhvete til økologisk dyrking og håndverksbakst (Quality grains for food - the potential of non-commercialized Norwegian varietal material. Studies of spring wheat for organic growing and artisan baking) (In Norwegian, with English summary). NORSØK report 5 (4) 2019 
MacPherson A, Dixon J (2003) Cobalt. Encyclopedia Food Sci Nutri:1431-1436

Martineau C (2016) Gluten-free? These heritage grains will lure you back Vogue daily https://wwwvoguecom/article/glutenfree-heritage-grains-change-your-mind Accessed 6 Mar 2020

Norwegian Agriculture Agency (2019) Markedsrapport 2019. Markeds- og prisvurderinger av sentrale norsk landbruksråvarer og RÅ-varer (Market report 2019. Market and price assessment of essential Norwegian agricultural products and processed agricultural products; in Norwegian). https://www.landbruksdirektoratet. no/no/produksjon-og-marked/korn-og-kraftfor/marked-ogpris/publikasjoner. Accessed 6 Mar 62020

Peltonen-Sainio P, Peltonen J (1994) Progress since the 1930s in breeding for yield, its components, and quality traits of spring wheat in Finland. Plant Breed 113:-177, 184. https://doi. org/10.1111/j.1439-0523.1994.tb00721.x

Research Council of Norway (RCN) (2020) Expanding the technology base for Norwegian wheat breeding: genomic tools for breeding of high-quality bread wheat. Project Bank. ht tps://prosjektbanken.forskning sradet. no/\#/project/NFR/256370/Sprak=no . Accessed 24 Mar 2020

Rich SM, Watt M (2013) Soil conditions and cereal root system architecture: review and considerations for linking Darwin and weaver. J Exp Bot 64:1193-1208. https://doi. org/10.1093/jxb/ert043

Vindras-Fouillet C, Ranke O, Anglade JP, Taupier-Letage B, Chable V, Goldringer I (2014) Sensory analyses and nutritional qualities of hand-made breads with organic grown wheat bread populations. Food Nutr Sci 5:1860-1874

Zhao FJ, Su YH, Dunham SJ, Rakszegi M, Bedo Z, McGrath SP, Shewry PR (2009) Variation in mineral micronutrient concentrations in grain of wheat lines of diverse origin. J Cereal Sci 49:290-295

Publisher's note Springer Nature remains neutral with regard to jurisdictional claims in published maps and institutional affiliations. 